\title{
MUSCLE ATTACHMENT IN INSECTS.*
}

William A. Riley.

As a rule, writers on insect histology have been content to state that the muscles are attached to the body-wall, without attempting to explain the mode of attachment. Within the past few years considerable attention has been paid to this phase of the subject, but there is little agreement in the views expressed and the question can by no means be regarded as closed. For some time, in connection with general work, the writer has paid special attention to this question, intending to make a study of the conditions in a wide series of insects. The comprehensive work of Snethlage, ' 05 , and his exhaustive review of the literature, have rendered superfluous extended publication of these results but it is desired to call attention here to some features of the subject which have not been emphasized, and especially to the striking conditions to be found in the nymphs of Anax, a dragon-fly.

Theoretically, considering the structure of the body-wall of an arthropod, the muscles may be attached in any one of the several different ways. The fibers may be fastened directly to the cuticula or they may be attached through the intermediary of the hypodermal cells.

In the first instance, either the muscle fibers would force their way between the hypodermal cells in order to reach the cuticula (text-figure $A$ ), or their fibrils would pass directly through the hypodermal cell-body; (text-figure $B$ ).

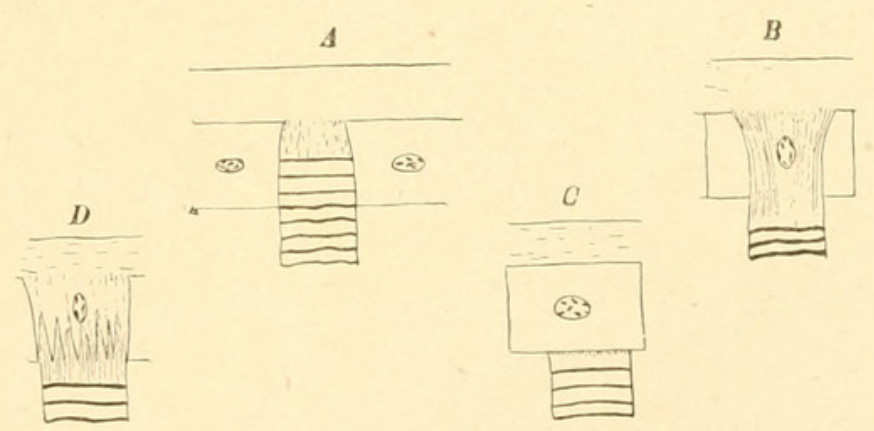

Fig. 6. Diagrams showing four possible methods of attachment of muscle fibers in arthropods. For explanation see text.

In case the attachment be through the intermediary of the hypodermal cells, the fibers might abut against the basement

*Contribution from the Entomological Laboratory of Cornell University. 
membrane, being soldered to the ceil, as in $C$, of the text-figure. Or, as in $D$, the union might be due to the interlacing or dovetailing of the muscle fibrils with those of the hypodermal cells.

Apparently clear illustrations of the direct passage of the muscle fibrils through the hypodermis are afforded by sections of the nymph of Chortophaga viridifasciata, an Acridid. Such a section is represented in the photomicrograph, plate XXIV, fig. I, and from the study of such sections alone there would be little question that the muscle fibrils are attached directly to the cuticula. Unless they have themselves become fibrilloid there is left at the point of muscle attachment but little trace of the hypodermal cells. They are clearly indicated by their nuclei, which are larger than those of the muscle and in which the distribution of the chromatin is also different. Moreover, their limits are shown by the very definite, dark-brown pigment granules similar to those found in the hypodermal cells of other regions.

Snethlage has pointed out that it is easy to see how an oblique section through the muscle and the overlying hypodermis would present, in some cases, the appearance shown in $C$, and thus lead to a misinterpretation. On the other hand, if an axial section presents the appearance shown in the photograph, it becomes a question of determining whether the prominent fibrils in the hypodermal cells are muscle fibrils, pushing through the cell as in $B$, or whether they are what Maziarski, 'o3, has aptly denominated tonomitomes, i. e., filaments of protoplasm differentiated in the epithelial cell itself, as a result of mechanical stimulus.

It was when examining some sections of the nymph of Anax, prepared by Dr. Needham for the study of wing development, that I had my attention attracted to striking evidence in favor of the view that muscle attachment in insects is through the intermediary of the hypodermal cells, as has been maintained by Weismann, '63, Leydig, '85, Bertkau, '85, Duboscq, '98, and others.

As may be seen from figure 2, the hypodermal cells in the region of the muscle attachment are very elongate and narrow, measuring about $50 \mu$ in length and $5 \mu$ in width. They are sharply differentiated by the haematoxylin-eosin stain, being much bluer than the attached muscles. Their nuclei are also distinct from those of the muscle fibers. The cells are feebly 
longitudinally striate but their fibrils appear finer than those of the muscle and there is no clear evidence of direct continuity of the two. On the contrary, I believe that there occurs a splicing or fusion of the two types of fibrils, the basement membrane being lacking at the point of contact,

The sections first studied were of alcoholic material, cut at Io $\mu$ and stained in haematoxylin and eosin. In order to make a more careful study material was fixed in Flemming's and in Gilson's fluids, sectioned at $2-3 \mu$ and stained in iron haematoxylin. The appearance was then very similar to that presented by the above mentioned sections of Chortophaga.

As may be seen from figure 3 , the striae are much more prominent and the muscle fibrils, as in Chortophaga, are apparently continued through the body of the hypodermal cells to attach directly to the cuticula. This appearance is greatly emphasized in the sections in which, as in figure 4 , the cuticular layer has been torn away. Then the distal ends of the cells present a frayed-out appearance, due to the projecting fibrils.

At the Chicago meeting of the American Association I exhibited lantern slides from these preparations and, emphasizing as they do, the appearances found by Snethlage in a large series of insects, I believed that they represented direct attachment of the muscle fibers to the cuticula. Studies of developing muscle in the postembryonic stages, and renewed examinations of the conditions in Anax and other forms have forced me to return to my first interpretation of the conditions.

Most instructive were sections through the developing wingmuscles of Anax such as represented by figures 5 and 6 . In these photographs there is to be seen an apodeme-like invagination of the body-wall, surrounded by its hypodermal cells. Near its apex these cells become suddenly greatly elongated, their nuclei become fusiform, and placed at the bases of the cells, while prominent longitudinal striae appear within them. The basement membrane is deflected to enclose the muscle fibers and, in fact, the whole appearance seems to support Snethlage's contention that the muscle fibers are hypodermal in origin, merely prolongations of the epithelial cells.

From my studies I am, however, unable to accept this view that the muscle fibers of the arthropods are structurally prolongations of the chitinogenous cells. Snethlage bases his theory on a study of the development of the musculature of the nauplii of 
Artemia salina, but I do not believe that even for this species his. evidence is conclusive, and I do not find any satisfactory evidence to overthrow the almost unanimous testimony of careful workers. in favor of the mesodermal origin of this tissue in insects. Snethlage objects that the concept of the inpushing of a special, independently originating tissue at definite points in the bodywall savors of the theory of "praestabilierten Harmonie" but this objection would no more hold than in the case of nerve endings, or others that might be cited. Moreover, he overlooks the fact that however the muscle originated, his own objection would still hold when its insertion is considered.

An important point to be considered in a study of the method of muscle attachment is the remarkable differentiation of the hypodermal cells in the region of the attachment. In many cases as in Anax, they become very greatly elongate and fibrilloid, as compared with the immediately neighboring cells of the bodywall. This is especially clearly seen in figure 5. If the muscles are attached directly to the cuticula, why should there be this great elongation of the epithelium? If, on the other hand, the attachment is through the intermediary of the hypodermal cells, it is just such a change which we might expect.

Van Rees, '89, found that in the thorax of the pupa of Musca the muscle tendons are developed in this manner, as prolongations of the hypodermal cells which grow inward to meet the developing muscle. Similar studies by Berlese, 'or, and by Silvestri, 'o3, lead them to declare emphatically in favor of the view that the attachment of the muscle is through the intermediary of the hypodermal cells.

Hecht, '99, has called attention to the remarkable appearance of the muscular insertions in the myrmicophilous dipterous larva, Microdon. In this form the fibrillated appearance can be traced not only through the hypodermal cells but through the total thickness of the greatly developed secondary cuticula, spreading out fan-like under the primary cuticula. Through the kindness of E. L. Jenne, I have had the opportunity of examining a number of sections of these larvae and find the fibrils very prominently developed but by no means as clearly muscular as Hecht's figures would indicate. A very similar condition is to be found in sections of Muscid larvae, though in the ones which I studied the arrangement of the fibrils was in the form of a cone with its base entad, rather than as in Microdon. In none of the cases were the 
conditions such as to preclude the purely hypodermal origin of these fibrils.

A number of writers, notably Tower, 'o6, have called attention to the fact that when the cuticula loosens, its attachment persists longer at the point of attachment of the muscles than elsewhere and they have thought to see in this proof of the view that the muscles were attached directly to the cuticula. Such evidence is by no means conclusive for as in the instances mentioned above, this condition might very well prevail in either case.

The whole problem is one of great interest and, as stated at the outset, can be by no means regarded as closed. I cannot believe with Sinety that we have the anomaly of both methods occurring within different species of even the same family of insects. The evidence very strongly supports Maziarski's view that the so-called muscular fibrils passing through the hypodermal cells are in reality modifications of its own protoplasm, - true tonomitomes.

BIBLIOGRAPHY.

For an extended bibliography see Snethlage's paper. There are given below only the papers referred to which are not listed by Snethlage.

1906. Berlese, A. Gli insetti. i, pp. 471-472. Brief review of Berlese, '01, and Silvestri, '03.

1903. Maziarski, S. Sur les rapports des muscles et de la cuticle chez les Crustacés. Bull. Ac. Sc. de Cracovie, 1903, pp. 520-531. P1. 14.

1889. Rees, J. van. Beiträge zur Kentniss der inneren Metamorphose von Musca vomitoria. Zool. Jahrb. Anat. iii, pp. 106-108 and fig. 14.

1905. Snethlage, E. Ueber die Frage von Muskelansatz und der Herkunft der Muskulatur bei den Arthropoden. Zool. Jahrb. Anat. xxi, pp. 495-514. Pls. 29-30.

1906. Tower, W. L. Observations on the changes in the hypodermis and cuticula of Coleoptera during ecdysis. Biol. Bull. x, pp. 188-189, and figs. $8,10,11$.

\section{EXPLANATION OF PLATE XXIV.}

Fig. 1. Muscle attachment in the nymph of Chortophaga viridifasciata, an Acridid.

Fig. 2. A portion of the body-wall of a nymph of Anax, showing the greatly elongated hypodermal cells at the point of attachment of the muscles.

Fig. 3. Muscle attachment in another individual of Anax.

Fig. 4. A preparation of Anax from which the cuticula has been broken away, showing the frayed-out ends of the hypodermal cells.

Fig. 5. An apodeme of a nymph of Anax, showing the greatly elongated hypodermal cells at the point of attachment of the developing muscle.

Fig. 6. The same, enlarged 


\section{$2 \mathrm{BHL}$ Biodiversity Heritage Library}

Riley, William A. 1908. "Muscle Attachment in Insects." Annals of the Entomological Society of America 1, 265-269.

https://doi.org/10.1093/aesa/1.4.265.

View This Item Online: https://www.biodiversitylibrary.org/item/38100

DOI: https://doi.org/10.1093/aesa/1.4.265

Permalink: https://www.biodiversitylibrary.org/partpdf/193711

\section{Holding Institution}

Smithsonian Libraries

\section{Sponsored by}

Smithsonian

\section{Copyright \& Reuse}

Copyright Status: NOT_IN_COPYRIGHT

This document was created from content at the Biodiversity Heritage Library, the world's largest open access digital library for biodiversity literature and archives. Visit BHL at https://www.biodiversitylibrary.org. 